\title{
The Effect of Specific Soil Microorganisms on Soil Quality Parameters and Organic Matter Content for Cereal Production
}

\author{
Arnoldas Jurys *(D) and Dalia Feizienè \\ Department of Plant Nutrition and Agroecology, Institute of Agriculture, Lithuanian Research Centre for \\ Agriculture and Forestry, Instituto al. 1, LT-58344 Akademija, Lithuania; dalia.feiziene@lammc.lt \\ * Correspondence: arnoldas.jurys@lammc.lt
}

Citation: Jurys, A.; Feizienė, D. The Effect of Specific Soil Microorganisms on Soil Quality Parameters and Organic Matter Content for Cereal Production. Plants 2021, 10, 2000. https://doi.org/10.3390/plants10102000

Academic Editor: Adriano Sofo

Received: 27 August 2021

Accepted: 17 September 2021

Published: 24 September 2021

Publisher's Note: MDPI stays neutral with regard to jurisdictional claims in published maps and institutional affiliations.

Copyright: (c) 2021 by the authors. Licensee MDPI, Basel, Switzerland. This article is an open access article distributed under the terms and conditions of the Creative Commons Attribution (CC BY) license (https:// creativecommons.org/licenses/by/ $4.0 /)$.

\begin{abstract}
Soil chemical, biological and physical properties play important roles in soil quality and are related with increasing organic matter content, soil microbiological activity, plant nutrient content and availability. A new generation of soil amendments, containing specific soil microorganisms, are of great interest worldwide. Field experiments were carried out in 2018-2019 at the Institute of Agriculture, Lithuanian Research Centre for Agriculture and Forestry. The aim was to determine the impact of bio-products containing Trichoderma reesei, Acinetobacter calcoaceticus or Bacillus megaterium, and their mixtures on changes of soil organic carbon (SOC), soil respiration, and microbial biodiversity in loamy Cambisol. Under dry meteorological conditions, Trichoderma reesei, Acinetobacter calcoaceticus and Bacillus megaterium bio-products resulted an increase in SOC content, $\mathrm{C} / \mathrm{N}$ ratio, humic to fulvic acid ratio, soil respiration, and microbial biodiversity. It is concluded that the use of a mixture of three microorganisms (Trichoderma reesei + Acinetobacter calcoaceticus + Bacillus megaterium) is the most promising bio-amendment under climate change. Future research is needed on different soil types and textures.
\end{abstract}

Keywords: soil organic carbon; plant-growth-promoting rhizobacteria; plant-growth-promoting fungi; microbial biodiversity

\section{Introduction}

Naturally, soil is a slowly renewable resource with a high degree of degradation and very low rate of regeneration [1]. Intensive agriculture leads to soil erosion, depletion of organic matter and other nutrients, which results in permanent soil degradation and significant productivity losses [2]. To maintain optimal yields and avoid soil depletion, it is necessary to protect soil from organic carbon and biodiversity losses, micronutrient imbalance, acidity, and salinity [3]. The use of microbial inoculants while developing sustainable agriculture techniques in chemical-based farming is one of the most promising alternatives these days [4]. Input of exogenous organic matter, such as straw or livestock manure, can enrich soil with the necessary elements and prevent soil organic matter (SOM) decomposition [5]. Soil quality parameters can be determined analyzing soil chemical, biological, and physical properties together [2,3]. To determine soil quality, indicators such as particulate organic matter (OM), active $\mathrm{C}$, total $\mathrm{N}$, microbial biomass, biological activities, enzymes, soil $\mathrm{pH}$, cation exchange capacity, salinity, bulk density, amino sugar, and soil aggregation should be known $[2,6]$. Soil microorganisms consist mainly of primary decomposers that mineralize organic materials and release nutrients and energy for plants by enzyme-facilitated metabolic systems $[2,6,7]$. Plant growth and yield in natural environments depend on many interactions between plant roots, bacteria, and fungi $[6,8]$. Regarding the decomposition of organic residues, microbial communities can be broken down into fungal and bacterial groups, and research indicates that these groups function differently in the decomposition processes $[9,10]$. Bacterial decomposition pathways support high turnover rates of easily available substances, fungal-dominated decomposition pathways are slower and includes degradation of complex organic materials $[6,9,10]$. It is 
known that the main plant-beneficial rhizosphere microorganisms are mycorrhiza, rhizobia bacteria, PGPR (plant-growth-promoting rhizobacteria) such as Pseudomonas spp., Bacillus spp. or Azospirillum spp., and PGPF (plant-growth-promoting fungi) such as Trichoderma spp. and non-pathogenic Fusarium spp. strains [7,10,11]. PGPR and PGPF colonize plant roots and are responsible for plant defense, protecting them not only from various foliar pathogens but also from leaf-feeding insects $[10,11]$.

In this research two strains of PGPR and 1 strain of PGPF were used. Acinetobacter calcoaceticus-a Gram-negative, rod-shaped $(0.9-1.6 \mu \mathrm{m}$ by $1.5-2.5 \mu \mathrm{m})$ in the intensive growth phase, aerobic soil bacterium belonging to the genus of Acinetobacter. In the growth phase it is normally grouped in pairs or chains. Acinetobacter calcoaceticus has no sporulation properties. The growth temperature mode is from 15 to $37^{\circ} \mathrm{C}$. Bacillus megaterium is a Gram-positive, rod-shaped $(2.0-5.0 \mu \mathrm{m}$ by $1.2-1.5 \mu \mathrm{m})$, mainly aerobic soil bacterium, belonging to the genus Bacillus. It is one of the largest known bacteria. Bacillus megaterium can form spores that can be ellipsoidal, spherical, central, paracentral or subterminal. Growth temperature depends on environment where it was extracted, and could be from 3 to $45^{\circ} \mathrm{C}$; the optimum is about $30^{\circ} \mathrm{C}$. Both bacteria are known for their phosphorusreleasing and nitrogen-fixing properties [12-14]. Trichoderma reesei is a filamentous fungus, widely distributed in places of soil and wood decomposition. This microscopic fungus is one of the main microorganisms used for the industrial production of biomass degrading enzymes $[15,16]$. Saprophytic fungus of the genus Trichoderma obtains its nutrients from dead and decaying plant matter. Trichoderma reesei is known as a plant cell wall degrader which efficiently produces enzymes which degrade plant cell wall compounds, such as cellulose, hemicellulose, and pectin [17]. Under special conditions after 1-3 weeks this fungi can form ascospores.

There is no literature concerning the influence and relationship of tillage with microorganisms. This study aims to determine the influence of specific soil microorganisms (PGPR and PGPF individually and in a complex) on soil organic carbon (SOC), soil respiration and biodiversity in loamy Cambisol under reduced tillage conditions.

We hypothesize that bio-products which contain Trichoderma reesei, Acinetobacter calcoaceticus or Bacillus megaterium and their mixtures will increase the SOC content, C/N ratio, humic to fulvic acid ratio, soil respiration and microbial biodiversity in loamy Cambisol.

The aim of research was to investigate the influence of new generation amendments on soil organic carbon content, soil vitality, and biodiversity.

\section{Results}

Microorganisms were selected from four different farming practices using selective media (Table 1). During microorganism isolation processes, the total number of microorganisms was not as relevant as the goal of finding specific microorganisms.

Table 1. Quantification of soil suspension, screening of bacteria and fungi-specific properties.

\begin{tabular}{ccccc}
\hline & $\begin{array}{c}\text { Chemical Farm with } \\
\text { Poor Crop Rotation }\end{array}$ & $\begin{array}{c}\text { Chemical Farm with 5 } \\
\text { Field Crop Rotations }\end{array}$ & Ecological Farm & $\begin{array}{c}\text { Natural } \\
\text { Meadows }\end{array}$ \\
\hline $\begin{array}{c}\text { Total amount of phosphorus } \\
\text { solubilizing bacteria CFU/g }\end{array}$ & $4.1 \times 10^{5}$ & $6.2 \times 10^{6}$ & $5.3 \times 10^{5}$ & $2.8 \times 10^{5}$ \\
\hline $\begin{array}{c}\text { Total amount of nitrogen fixing } \\
\text { bacteria CFU/g }\end{array}$ & $3.1 \times 10^{6}$ & $8.1 \times 10^{6}$ & $3.8 \times 10^{5}$ & $3.1 \times 10^{5}$ \\
\hline Total amount of fungi CFU/g & $2.7 \times 10^{4}$ & $2.5 \times 10^{5}$ & $2.1 \times 10^{4}$ & $3.2 \times 10^{4}$ \\
\hline Sample $\mathrm{pH}$ & 7.72 & 7.31 & 6.91 \\
\hline
\end{tabular}

After screening for specific microorganisms and evaluating the possibility of nitrogen fixation and phosphorus solubilization, it was decided to continue field trials with microorganisms isolated from a chemical farm with five field crop rotations and natural meadows. From the chemical farm with five field crop rotations, two isolated microorganisms were 
selected. The isolated bacterial strain had very good phosphate solubilization properties and good nitrogen fixation properties. Due to phenotypic traits and formation of yellow pigment after $48 \mathrm{~h}$ of cultivation, it was thought to be Bacillus megaterium. Purified microscopic fungal culture had similar phenotypic traits to Trichoderma spp. The bacterial strain isolated from natural meadows had great phosphate solubilization and nitrogen fixation properties, and also grew faster than bacteria selected from the chemical farm.

Selected microorganism cultures were purified to a single colony before samples were sequenced and identified. For confirmation, results were double checked in public databases. The bacteria which was isolated from natural meadows was Acinetobacter calcoaceticus with a $99.94 \%$ match. As expected, samples from the chemical farm with five field crop rotations had a 99.99\% match with Bacillus megaterium, and Trichoderma reesei had $100.00 \%$ similarity.

According to the SOC content, the soil of experimental fields could be classified as having a low SOC content. At the beginning of the experiment, SOC ranged from 0.91 to 0.93\%. During 2018-2019 seasons (Figure 1), the average SOC content was higher in all treatments with microorganisms, compared to control 1 (K1) and control 2 (K2). In 2018, the highest SOC concentration had been in treatment 3 (Trichoderma reesei). This was 10.0\% higher than in $\mathrm{K} 1$ and 7.1\% higher than in K2. In 2019, the highest SOC was in treatment 5 (Bacillus megaterium), i.e., $7.5 \%$ higher compared to $\mathrm{K} 1$ and $6.2 \%$ higher compared to K2.

1.10

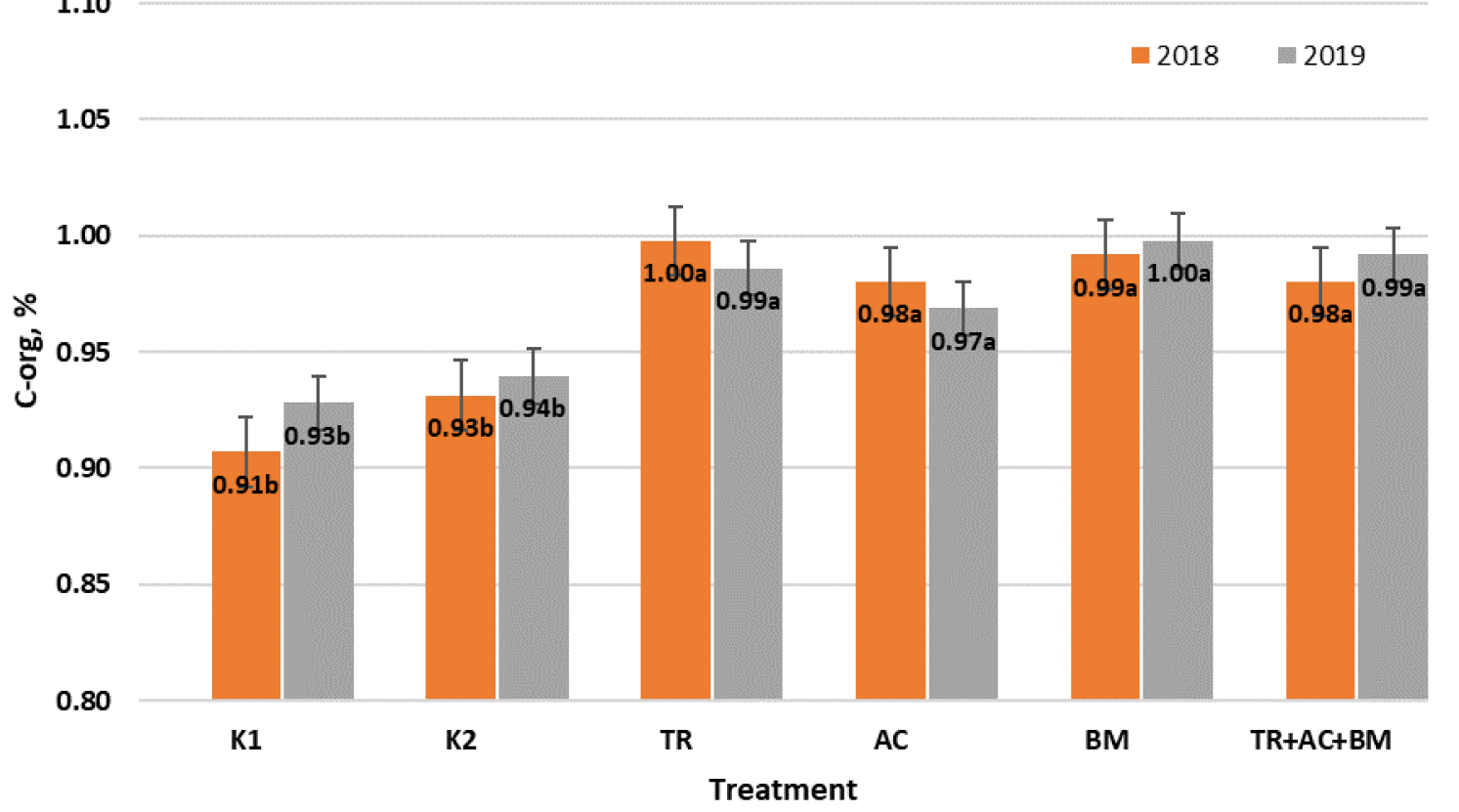

Figure 1. Average organic carbon concentration of soil during 2018-2019 field experiments. Different letters in blocks indicate significant differences in 2018 and 2019 ( $p<0.05)$. K1-control 1, K2-control 2, TR-Trichoderma reesei, AC-Acinetobacter calcoaceticus, BM-Bacillus megaterium, TR + AC + BM-Trichoderma reesei + Acinetobacter calcoaceticus + Bacillus megaterium.

The decomposition intensity of organic matter is best determined by the $\mathrm{C} / \mathrm{N}$ ratio. In the 2018 period the $\mathrm{C} / \mathrm{N}$ ratio (Figure 2) was $11.4 \%$ higher in treatment 6 (Trichoderma reesei, Acinetobacter calcoaceticus, Bacillus megaterium) compared to K1 and 10.3\% higher compared to K2. In the 2019 period the $\mathrm{C} / \mathrm{N}$ ratio (Figure 2) was highest in treatment 6; which was $4.7 \%$ higher than $\mathrm{K} 1$ and $7.3 \%$ than $\mathrm{K} 2$. The increased $\mathrm{C} / \mathrm{N}$ ratio during the experimental period means that the ratio of mineralization/humification processes changed. 


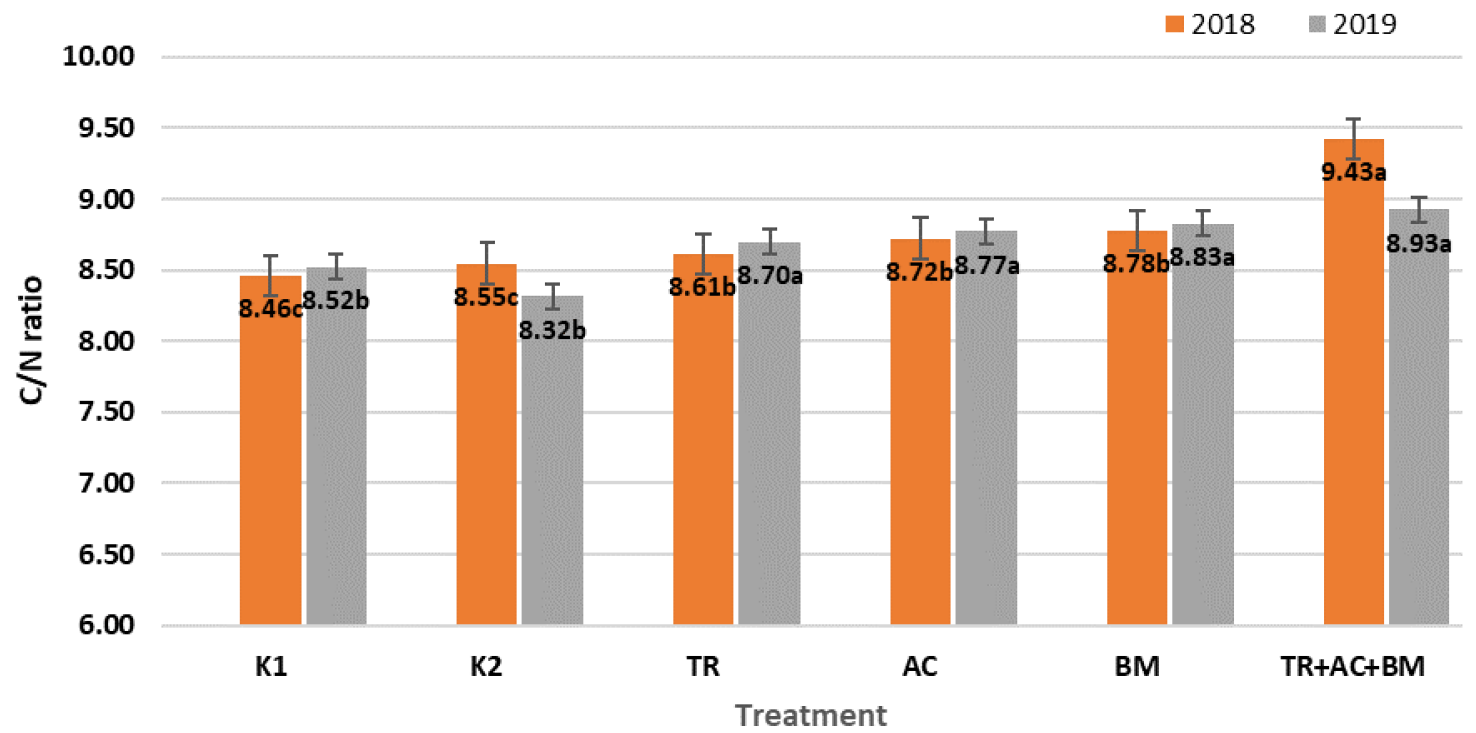

Figure 2. Average C/N ratio during 2018-2019 field experiments. The different letters in blocks indicate significant differences in 2018 and 2019 ( $p$ < 0.05). K1—control 1, K2—control 2, TR—Trichoderma reesei, AC—Acinetobacter calcoaceticus, BM-Bacillus megaterium, TR + AC + BM-Trichoderma reesei + Acinetobacter calcoaceticus + Bacillus megaterium.

Soil humus, especially its stable fractions, is formed slowly, so this indicator does not fully reflect the humification processes of embedded organic matter. The high humus content and low humic and fulvic acid ratio indicate that this humus is not long-lasting and the humification processes in such soils were weak. The humic to fulvic acid ratio was measured in 2019. Highest humic to fulvic (Figure 3) ratio was in treatment 6 (Trichoderma reesei, Acinetobacter calcoaceticus, Bacillus megaterium)—106.1\% higher than K1 and $94.3 \%$ higher than $\mathrm{K} 2$.

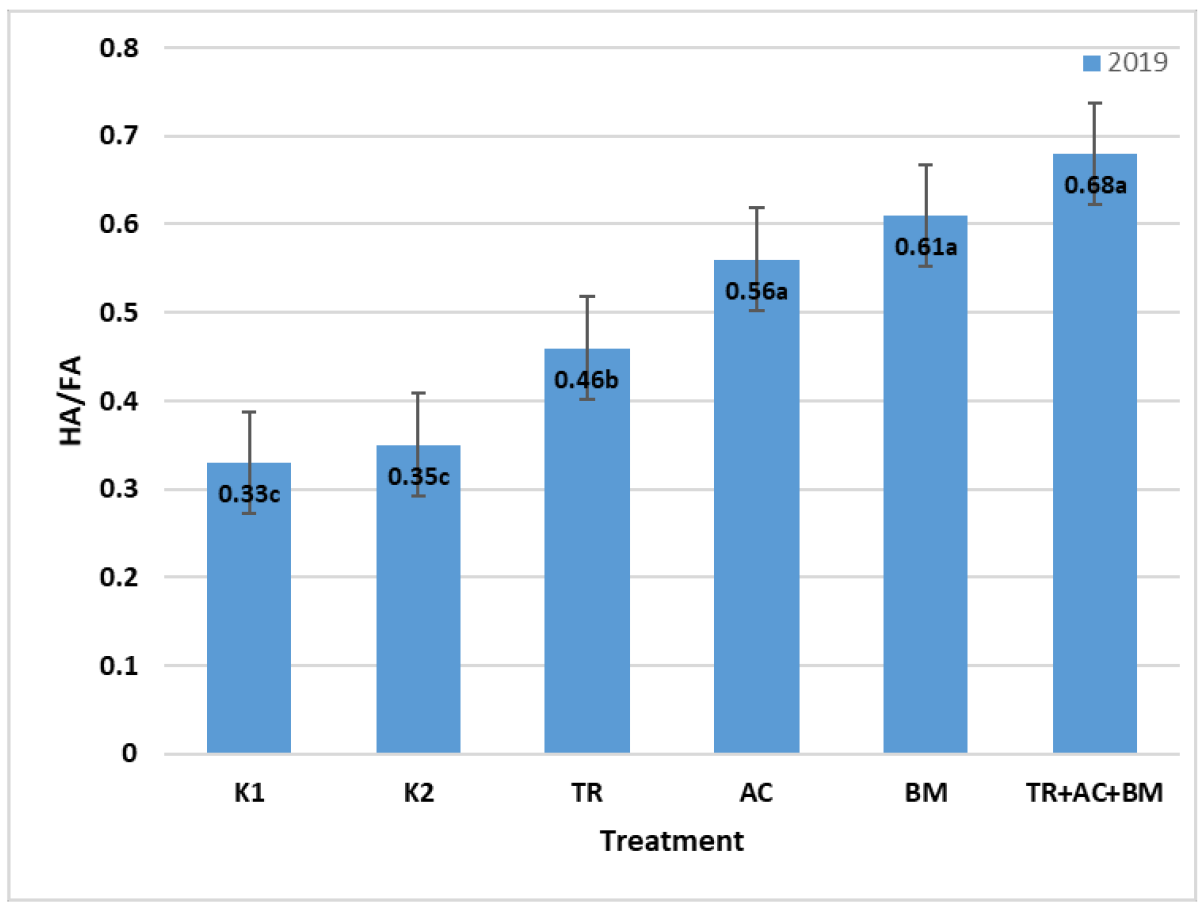

Figure 3. Average humic to fulvic acid ratio in 2019. The different letters in blocks indicate significant differences in 2019 ( $p$ < 0.05). K1-control 1, K2—control 2, TR-Trichoderma reesei, AC-Acinetobacter calcoaceticus, $\mathrm{BM}-$ Bacillus megaterium, $\mathrm{TR}+\mathrm{AC}+\mathrm{BM}$-Trichoderma reesei + Acinetobacter calcoaceticus + Bacillus megaterium. 
During the period of experiment, the soil NCER mean (Figure 4) was highest in treatment 6 (Trichoderma reesei + Acinetobacter calcoaceticus + Bacillus megaterium). In 2018, the NCER mean was higher by $26.3 \%$, compared to both K1 and K2. In 2019, the NCER mean was $23.4 \%$ higher than in K1 and 33.3\% higher than K2.

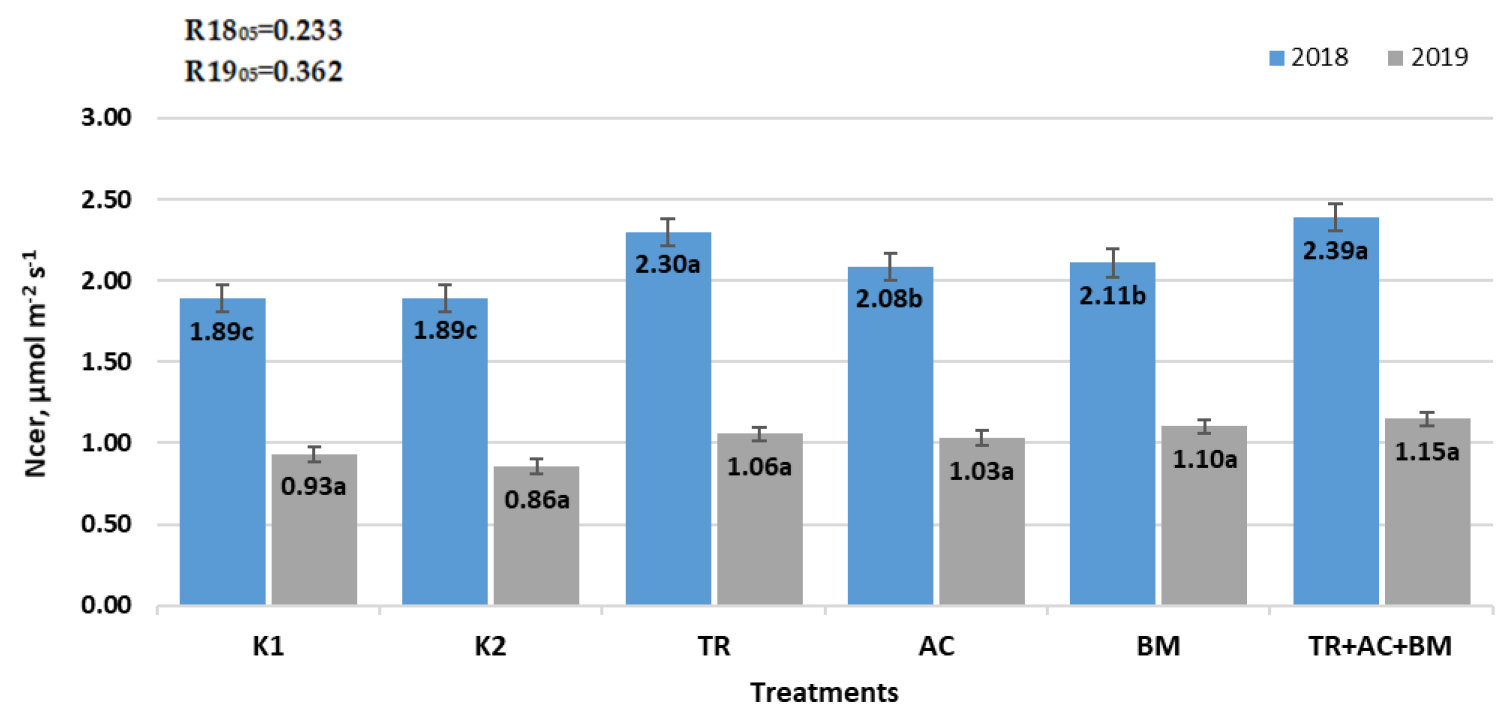

Figure 4. Average soil net $\mathrm{CO}_{2}$ exchange rate. The different letters in blocks indicate significant differences in 2018 and 2019 $(p<0.05)$. K1-control 1, K2-control 2, TR—Trichoderma reesei, AC—Acinetobacter calcoaceticus, BM-Bacillus megaterium, $\mathrm{TR}+\mathrm{AC}+\mathrm{BM}-$ Trichoderma reesei + Acinetobacter calcoaceticus + Bacillus megaterium.

To compare the strategy of substrate consumption by the soil microbiomes, the matters were contained in a Biolog EcoPlate and were classified into six main groups: carbohydrates, carboxylic acids, polymers, amino acids, amines, amides and miscellaneous. Data revealed that in both dry experimental years carboxylic acids were dominating. In 2018 they consisted of $28-32 \%$ and in $2019,28-31 \%$ of all substrate $C$ sources (Figures 5 and 6 ). The amount of carbohydrates was $21-23 \%$ and $25-28 \%$, amino acids $19-20 \%$ and $17-20 \%$, polymers $14-16 \%$, amines $4-6 \%$ and $4-5 \%$, and miscellaneous $8 \%$ and $5-8 \%$, respectively.

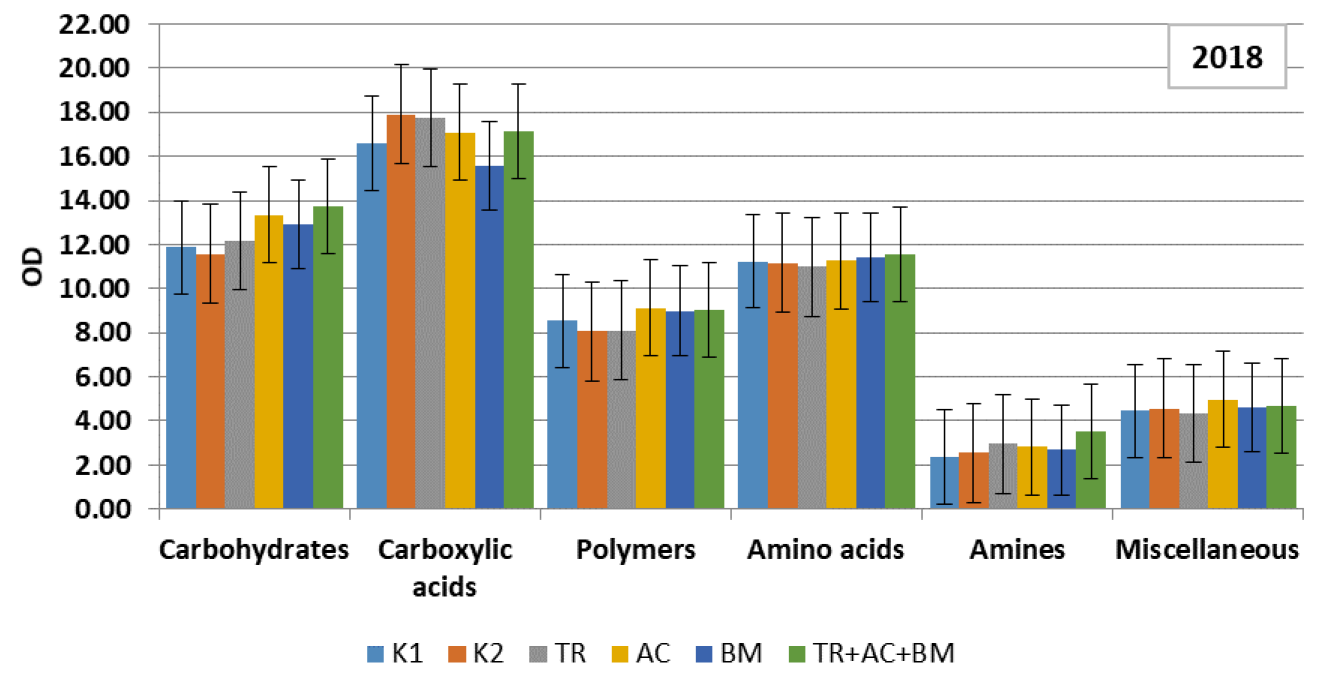

Figure 5. Level of consumption of substrates by microbial communities of soil in 2018. On the y axis OD—optical density, on the $\mathrm{x}$ axis, carbon sources. $\mathrm{K} 1$ - control 1, K2-control 2, TR-Trichoderma reesei, AC—Acinetobacter calcoaceticus, BM-Bacillus megaterium, TR + AC + BM-Trichoderma reesei + Acinetobacter calcoaceticus + Bacillus megaterium. 
In the first dry year, the influence of soil microbiological amendments on $C$ sources of the soil substrate were insignificant (Figure 5). In the next dry year, all products caused significantly higher optical density (OD) values in each substrate category, compared to both controls. The most significant effect was revealed in the combined application of treatment 6 (Trichoderma reesei, Acinetobacter calcoaceticus, Bacillus megaterium) (Figure 6). High levels of carbohydrates and carboxylic acids in substrate consumption may relate to the complexity of these substrates.

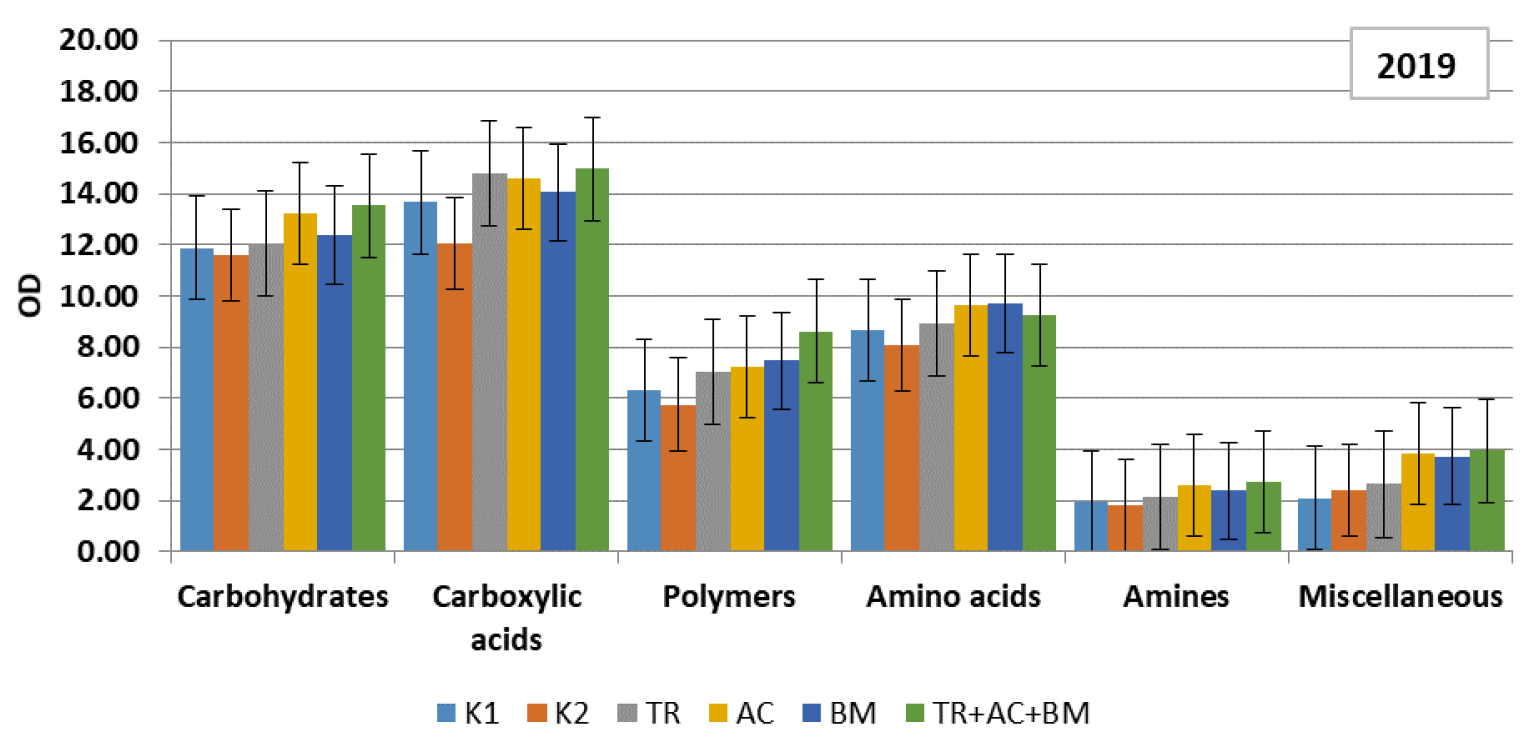

Figure 6. Level of consumption of substrates by microbial communities of soil in 2019. On the y axis OD—optical density, on the $\mathrm{x}$ axis, carbon sources. K1—control 1, K2—control 2, TR—Trichoderma reesei, AC—Acinetobacter calcoaceticus, BM-Bacillus megaterium, $\mathrm{TR}+\mathrm{AC}+\mathrm{BM}$-Trichoderma reesei + Acinetobacter calcoaceticus + Bacillus megaterium.

Principle Components Analysis (PCA) of average well color development (AWCD) data revealed that during the first 4 days of the investigation, average well color development (AWCD) had grown in all selected samples. This index shows that microbial community metabolic activity was high, which may relate to carbon substrates. In 2018, on the 4th day of incubation, the highest AWCD index was found in treatment 6 (Trichoderma reesei, Acinetobacter calcoaceticus, Bacillus megaterium), which was 21-22\% higher than in $\mathrm{K} 1$ and K2. Meanwhile, treatments 3-5 differed from controls K1 and K2 by only 3-8\%.

In 2019, on the 4th day of incubation, the highest AWCD index was also found in treatment 6 (Trichoderma reesei, Acinetobacter calcoaceticus, Bacillus megaterium), which was $22-28 \%$ higher than in $\mathrm{K} 1$ and $\mathrm{K} 2$ treatments. Treatments $3-5$ differed by only $8-13 \%$ from controls $\mathrm{K} 1$ and $\mathrm{K} 2$ (Figure 7).

The richness $(R)$ index showed that the microbial diversity varied depending on the type of soil management technique, and generally increased when the combined application of microbiological products in treatment 6 (Trichoderma reesei, Acinetobacter calcoaceticus, Bacillus megaterium) were used (Figure 8). Microbial richness varied significantly $(p<0.05)$ in both experimental years. In 2018 the highest $\mathrm{R}$ value was determined in treatment 6 (Trichoderma reesei, Acinetobacter calcoaceticus, Bacillus megaterium) and was 4-5\% higher than in $\mathrm{K} 1$ and $\mathrm{K} 2$ treatments. Meanwhile, differences from controls $\mathrm{K} 1$ and $\mathrm{K} 2$ and treatments 3-5 were insignificant. In 2019, the highest $\mathrm{R}$ value was determined in treatments 4 (Acinetobacter calcoaceticus) and 6 (Trichoderma reesei, Acinetobacter calcoaceticus, Bacillus megaterium). The R index was $6-7 \%$ and $7-8 \%$ higher, respectively, than in $\mathrm{K} 1$ and $\mathrm{K} 2$. The correlation between AWCD and R indices was very high $(\mathrm{r}=0.91-0.95)$. Increased values of ACWD and $\mathrm{R}$ is likely related with SOC increase. 


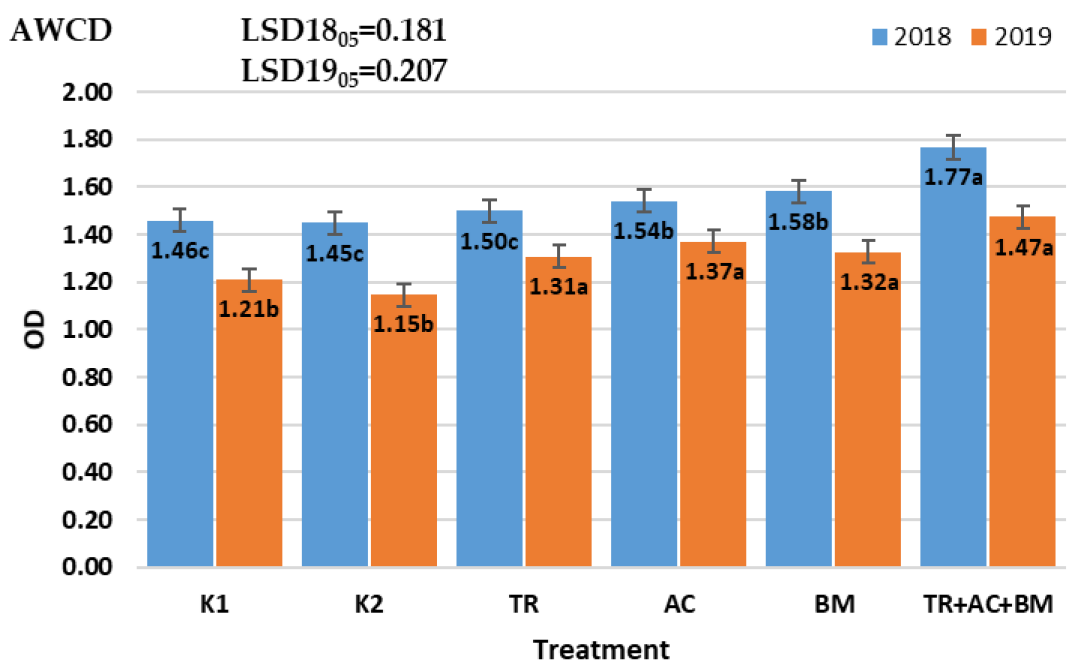

Figure 7. Influence of microbiological amendments on AWCD. The different letters in blocks indicate significant differences in 2018 and 2019 ( $p$ < 0.05). K1—control 1, K2-control 2, TR-Trichoderma reesei, AC-Acinetobacter calcoaceticus, $\mathrm{BM}-$ Bacillus megaterium, $\mathrm{TR}+\mathrm{AC}+\mathrm{BM}-$ Trichoderma reesei + Acinetobacter calcoaceticus + Bacillus megaterium.

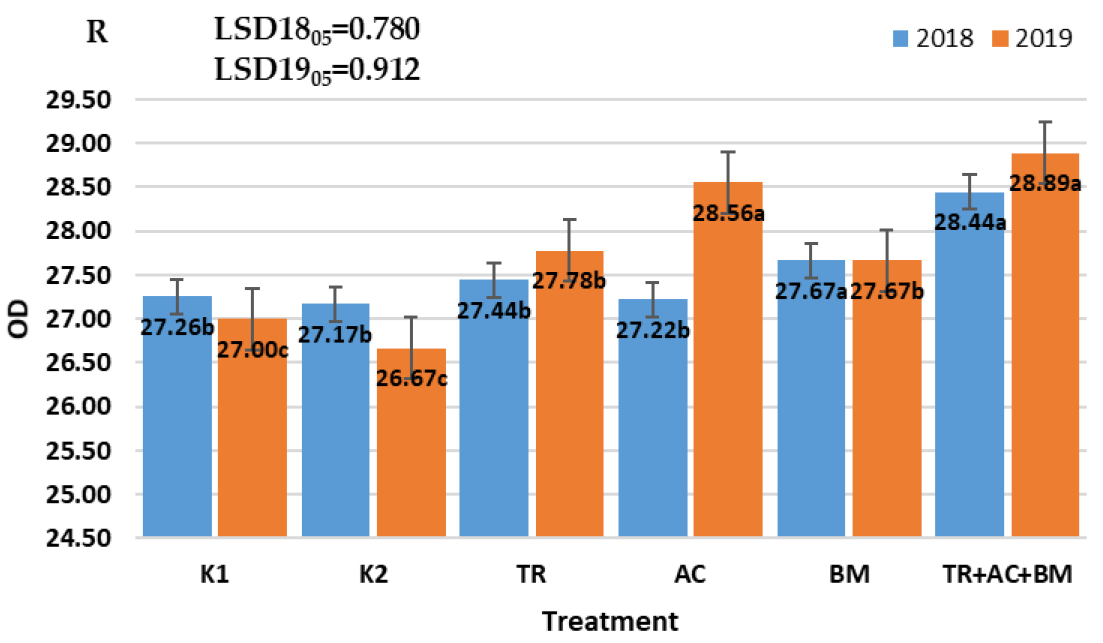

Figure 8. Influence of microbiological amendments on soil $\mathrm{R}$ index. The different letters in blocks indicate significant differences in 2018 and 2019 ( $p$ < 0.05). K1—control 1, K2-control 2, TR-Trichoderma reesei, AC-Acinetobacter calcoaceticus, $\mathrm{BM}-$ Bacillus megaterium, $\mathrm{TR}+\mathrm{AC}+\mathrm{BM}-$ Trichoderma reesei + Acinetobacter calcoaceticus + Bacillus megaterium.

From an agronomic point of view, the most valuable aggregates are those that do not decompose when exposed to water and can retain their stability for a long time. Overall, the stability of soil aggregates in the experimental field was good.

The stability of all aggregates in the top arm layer $(0-10 \mathrm{~cm})$ were higher than $53 \%$ (Figure 9) and in the lower arm layer $(10-20 \mathrm{~cm}$ ) (Figure 10) even reached $48 \%$. Stable aggregates $(0.25-1 \mathrm{~mm})$ in the top arm layer $(0-10 \mathrm{~cm})$ on average reached $47.8 \%$ and $43.22 \%$ in the lower arm layer $(10-20 \mathrm{~cm})$. Aggregates of size $>1 \mathrm{~mm}$ was $7.40 \%$ in the top arm layer $(0-10 \mathrm{~cm})$ and reached $6.80 \%$ in the lower arm layer. These results show that the physical soil structure was in good condition. During this experiment the differences of aggregate stability depended on the preparations used. In the top soil layer $(0-10 \mathrm{~cm})$, treatments 3 (Trichoderma reesei) and 6 (Trichoderma reesei, Acinetobacter calcoaceticus, Bacillus megaterium) were $4.9-8.8 \%$ higher than in $\mathrm{K} 1$ and $7.3 \%$ and $11.3 \%$ than $\mathrm{K} 2$. In the lower arm layer $(10-20 \mathrm{~cm}$ ), treatments 5 (Bacillus megaterium) and 6 (Trichoderma reesei, Acinetobacter 
calcoaceticus, Bacillus megaterium) showed the best results, which were $4.5 \%$ and $8.9 \%$ higher than in $\mathrm{K} 1$ and $2.7 \%$ and $7.0 \%$ than $\mathrm{K} 2$.

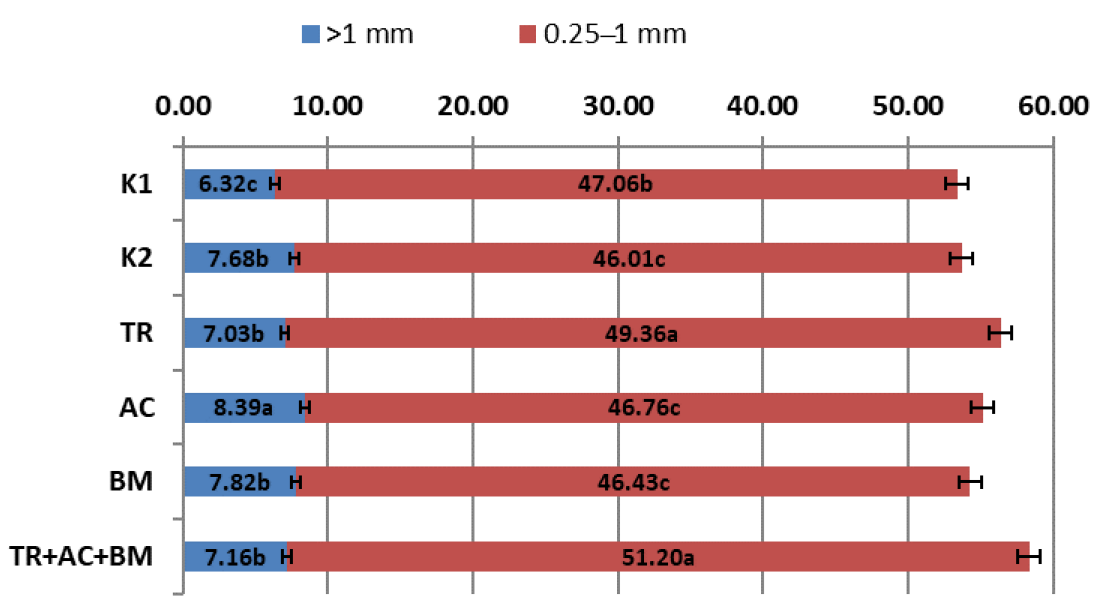

Figure 9. Stability of soil aggregates in the $0-10 \mathrm{~cm}$ layer. The different letters in blocks indicate significant differences in 2018 and 2019 ( $p$ < 0.05). K1-control 1, K2-control 2, TR-Trichoderma reesei, AC-Acinetobacter calcoaceticus, $\mathrm{BM}-$ Bacillus megaterium, $\mathrm{TR}+\mathrm{AC}+\mathrm{BM}-$ Trichoderma reesei + Acinetobacter calcoaceticus + Bacillus megaterium.

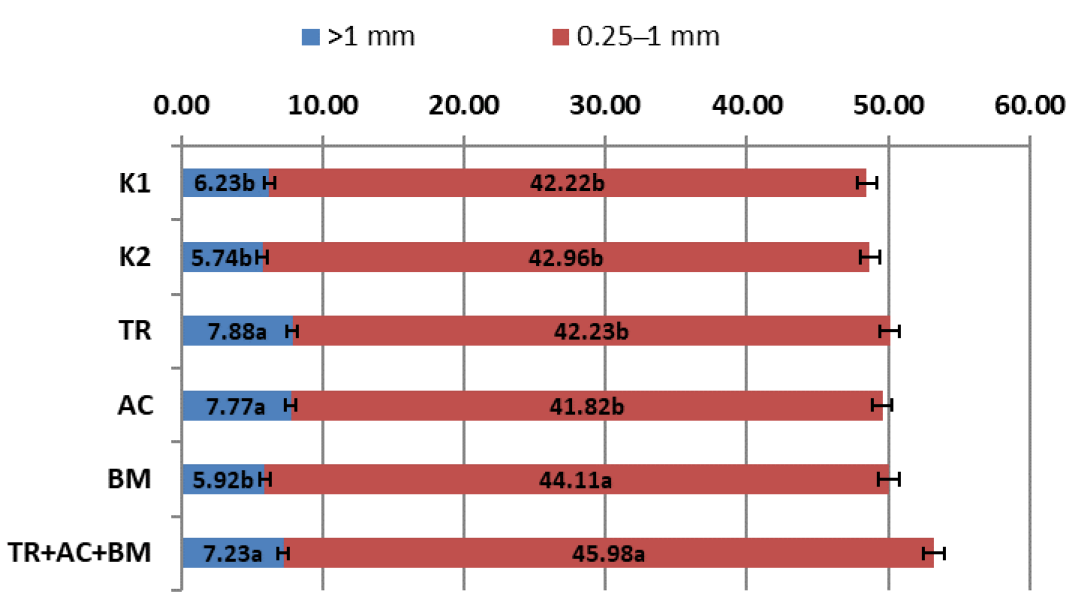

Figure 10. Stability of soil aggregates in the 10-20 cm layer. The different letters in blocks indicate significant differences in 2018 and 2019 ( $p$ < 0.05). K1—control 1, K2-control 2, TR-Trichoderma reesei, AC-Acinetobacter calcoaceticus, $\mathrm{BM}-$ Bacillus megaterium, $\mathrm{TR}+\mathrm{AC}+\mathrm{BM}-$ Trichoderma reesei + Acinetobacter calcoaceticus + Bacillus megaterium.

\section{Discussion}

Climate change and production intensification conditioned significant changes in the soil environment. Poor agricultural management practices and conditions granted by water, wind, or tillage erosion cause notable loses of the valuable topsoil layer [15]. The whole complex has a negative impact on soil microbial activity [15]. Therefore, worldwide there has been increased interest in the application of microbial amendments that provide natural benefits for soil and crops. Under commercial field conditions, microbial amendments can play an important role in environmental and human health protection [16].

Securing and improving soil quality is the main challenges to face when humanity is dealing with climate change. Considering the importance of the microbiota in soil ecosystems, the exploitation of microbial activity could have a great impact on soil properties improvement. The application of microbial amendments could improve usage of plant nutrients, reduce their release into soil and water, and consequently reduce negative effects to the environment [17]. 
The agrosector has used several strategies to rebuild the soil fertility. Most prevalent are livestock manure (fresh, composted, or solid fractions) from various species (cattle, hogs, poultry) or other amendments derived from agriculture including crop residues (straw, legumes) or spent mushroom compost $[5,15]$. These substances are also processed by specific soil microorganisms. When using these materials, it is important to ensure that efficient microorganisms dominate during the degradation processes, because this may subsequently have an impact on the biodiversity of microorganisms in the future $[4,15,18]$.

Our results obtained are in line with other published data. We found positive effects of microbiological soil amendments on Cambisol properties. Bio-products with Trichoderma reesei, Acinetobacter calcoaceticus and Bacillus megaterium caused increases in the SOC content, $\mathrm{C} / \mathrm{N}$ ratio, humic to fulvic acid ratio, and improved soil vitality by increasing soil respiration. We suppose that such results were governed by changes in soil physical properties. Pore structure, soil aggregate stability and water retention are under investigation in our experiment. Similar results were reported from sodic soils [19].

Bio-products act through a complex mechanism including plant roots, nitrogen fixation, P-solubilization, excretion of phytohormones, production of substances suppressing phytopathogens, guarding plants from abiotic and biotic stresses and detoxification of belowground pollutants, etc. [20-23]. Therefore, we think that the new generation of microbiological products could be advantageous under intensive farming conditions in commercial agriculture.

\section{Materials and Methods}

\subsection{Site and Soil Description}

The field experiments were conducted in 2018-2019 at the Institute of Agriculture, Lithuanian Research Centre for Agriculture and Forestry ( $55^{\circ} 23^{\prime} 50^{\prime \prime} \mathrm{N}$ and $23^{\circ} 51^{\prime} 40^{\prime \prime} \mathrm{E}$ ). The prevailing soil was Endocalcari-Epihypogleyic Cambisol (CMg-n-w-can). The composition of soil aggregates was $52-54 \%$ sand $(2.0-0.05 \mathrm{~mm}), 29-32 \%$ silt $(0.05-0.002 \mathrm{~mm})$ and $14-19 \%$ clay $(<0.002 \mathrm{~mm})$; soil was loam. Research scheme and product applications are described in Table 2. During 2018-2019 two crops were grown: winter wheat (Triticum aestivum L.) cv. Ada and spring barley (Hordeum vulgare L.) cv. Luokè. A field experiment was set up in four replications. The gross plot size and net harvested area of each individual treatment was 30.0 and $22.0 \mathrm{~m}^{2}$, respectively.

Table 2. Research design used the following doses of microorganisms: Trichoderma reesei-100 mL/ha, Bacillus megaterium$100 \mathrm{~mL} / \mathrm{ha}$, Acinetobacter calcoaceticus - $100 \mathrm{~mL} / \mathrm{ha}$, ammonium nitrate-10 kg N/t residues.

\begin{tabular}{|c|c|c|c|}
\hline \multirow[b]{2}{*}{ Treatments } & \multirow[b]{2}{*}{ Abbreviations } & \multicolumn{2}{|c|}{ Application of Bioproducts } \\
\hline & & $\begin{array}{c}\text { After Harvesting-For } \\
\text { Decomposition of Organic Residues }\end{array}$ & $\begin{array}{l}\text { After Germination } \\
\text { BBCH12-15 }\end{array}$ \\
\hline Control 1 & K1 & - & - \\
\hline Control 2 & $\mathrm{~K} 2$ & ammonium nitrate & - \\
\hline Trichoderma reesei & TR & Trichoderma reesei & \\
\hline Acinetobacter calcoaceticus & $\mathrm{AC}$ & - & Acinetobacter calcoaceticus \\
\hline Bacillus megaterium & $\mathrm{BM}$ & - & Bacillus megaterium \\
\hline $\begin{array}{l}\text { Trichoderma reesei }+ \text { Acinetobacter } \\
\text { calcoaceticus }+ \text { Bacillus megaterium }\end{array}$ & $\mathrm{TR}+\mathrm{AC}+\mathrm{BM}$ & Trichoderma reesei & $\begin{array}{c}\text { Acinetobacter calcoaceticus + } \\
\text { Bacillus megaterium }\end{array}$ \\
\hline
\end{tabular}

\subsection{Soil Sampling and Analysis}

Total nitrogen $\left(\mathrm{N}_{\text {tot }}\right)$ and total carbon $\left(\mathrm{C}_{\text {tot }}\right.$ for estimation of $\mathrm{C} / \mathrm{N}$ ratio) were analyzed by the dry combustion method using a CNS autoanalyser Vario EL III (Elementar Analysensystem $\mathrm{GmbH}$, Germany) [21,24]. The closed chamber method was applied to quantify the total (autotrophic + heterotrophic) soil surface net $\mathrm{CO}_{2}$ exchange rate (NCER). $\mathrm{CO}_{2}$ fluxes were measured five times during each crop growing season, each measurement was 
made between 10 a.m. and 12 a.m. using a portable infrared $\mathrm{CO}_{2}$ analyzer (IRGA) attached to a data logger (LcSRS-1000; ADC BioScientific Ltd., UK). In each treatment, the collar was inserted to $7.0 \mathrm{~cm}$ soil depth; the chamber hood was placed on the collar for 5 min until results were recorded in the data logger. Measurements were made with four replications. Expression of soil surface net $\mathrm{CO}_{2}$ exchange rate:

$$
\mathrm{NCER}=\mathrm{u}(-\Delta \mathrm{c})
$$

where $\mathrm{u}$ is the molar flow of air per square meter of soil $\left(\mathrm{mol} \mathrm{m}^{-2} \mathrm{~s}^{-1}\right)$ and $\Delta \mathrm{c}$ is difference in $\mathrm{CO}_{2}$ concentration through soil hood, dilution corrected $\left(\mu \mathrm{mol} \mathrm{mol}^{-1}\right)$.

Humic acid and fulvic acid were determined according to the "Agricultural Chemical Analysis, Method 5.4. Cabi Publishing, 2002" gravimetric and spectroscopic methods.

Substrate utilization potential as average well color development (AWCD) and the R index of the soil microbial community were determined according to the community level physiological profiles method using Biolog EcoPlates [22,25].

Soil water aggregate stability was determined by the wet sewing method with a Eijkelkamp Agriseerch Equipment apparatus (the Netherlands). Soil samples were taken at randomly selected sampling points at two places of each individual plot from the 0-10 and 10-20 cm layers (4 replicates per each layer for each treatment).

\subsection{Soil Samples for Microorganism Extraction}

Soil samples for microorganism extraction were collected from chemical farms with poor crop rotation, chemical farms with 5 field crop rotations, ecological farms, and natural meadows in the territory of the Republic of Lithuania. In each area, samples were collected from 5 different points with selected sites at a depth of $0-15 \mathrm{~cm}$. The samples were mixed well to represent a single sample. After mixing, the sample was weighed for microbiological analysis, an air-dried sample was used to determine the $\mathrm{pH}(\mathrm{KCl})$. The $\mathrm{pH}$ value was measured for each sample.

\subsection{Isolation of Microorganisms}

Isolation of phosphorus-releasing/solubilizing microorganisms was routinely screened by a plate assay method using Pikovskaya (PVK) agar. The PVK medium was used for pre-selection (Table 3). Microorganisms showing the best results were transferred to the National Botanical Research Institute's (NBRIY) (Table 3) phosphate growth medium to avoid the yeast extract effect [26,27].

Table 3. Composition of media used for phosphorus solubilizing microorganisms g/L.

\begin{tabular}{ccc}
\hline \multicolumn{2}{c}{ Pikovskaya (PVK) Agar } & National Botanical Research Institute's Phosphate Growth Medium (NBRIY) \\
\hline Glucose & 10.0 & 10.0 \\
\hline Yeast Extract & 0.5 & - \\
\hline$\left(\mathrm{NH}_{4}\right)_{2} \mathrm{SO}_{4}$ & 0.5 & 0.5 \\
\hline $\mathrm{MgSO}_{4} \cdot 7 \mathrm{H}_{2} \mathrm{O}$ & 0.1 & 0.1 \\
\hline $\mathrm{Ca}_{3}\left(\mathrm{PO}_{4}\right)_{2}$ & 5.0 & 5.0 \\
\hline $\mathrm{NaCl}$ & 0.2 & 0.2 \\
\hline $\mathrm{KCl}$ & 0.2 & 0.2 \\
\hline $\mathrm{MnSO}_{4} \cdot 2 \mathrm{H}_{2} \mathrm{O}$ & 0.002 & 0.002 \\
\hline $\mathrm{FeSO}_{4} \cdot 7 \mathrm{H}_{2} \mathrm{O}$ & 0.002 & 0.002 \\
\hline $\mathrm{Agar}^{2}$ & 15.0 & 15.0 \\
\hline
\end{tabular}

Phosphorus-releasing/solubilizing microorganisms were isolated from each sample by serial dilution and spread plate method. First, 10 grams $(10 \pm 0.2 \mathrm{~g})$ of soil sample was 
dispersed in $90 \mathrm{~mL}$ of autoclaved $0.9 \%$ saline and mixed with a magnetic stirrer for $30 \mathrm{~min}$. Serial dilutions to $10^{-5}$ were made for each soil sample, $0.1 \mathrm{ml}$ of each dilution was spread on Pikovskaya's agar medium containing insoluble tricalcium phosphate and incubated at $30{ }^{\circ} \mathrm{C}$ for 3 days. The suitable colony counting range was $25-250$ colonies per plate. Colonies showing halo zones were picked and purified [26,27]. Colonies of microorganisms that were able to form a halo zone were transferred to a new Petri dish with selective medium to check that the solubilization was not due to the influence of the surrounding microorganisms. The purified monoculture was transferred again to a selective medium to check whether the microorganism had not lost its phosphorus-releasing properties.

For isolation and preselection of nitrogen fixing bacteria Jensen's Medium was used (Table 4). First, 10 grams ( $10 \pm 0.2 \mathrm{~g})$ of soil sample was dispersed in $90 \mathrm{~mL}$ of autoclaved $0.9 \%$ saline and mixed with magnetic stirrer for $30 \mathrm{~min}$. Serial dilutions to $10^{-5}$ were made for each soil sample, $0.1 \mathrm{ml}$ of each dilution was spread on Jensen's Medium and incubated at $30{ }^{\circ} \mathrm{C}$ for 3 days. Bacteria able to grow on a nitrogen-free medium were picked and purified. The suitable colony counting range was $25-250$ colonies per plate.

Table 4. Composition of Jensen's Medium g/L.

\begin{tabular}{cc}
\hline Sucrose & 20.0 \\
\hline $\mathrm{K}_{2} \mathrm{HPO}_{4}$ & 1.0 \\
\hline $\mathrm{MgSO}_{4}$ & 0.5 \\
\hline $\mathrm{NaCl}$ & 0.5 \\
\hline $\mathrm{FeSO}_{4}$ & 0.1 \\
\hline $\mathrm{Na}_{2} \mathrm{MoO}_{4}$ & 0.005 \\
\hline $\mathrm{CaCO}_{3}$ & 2.0 \\
\hline $\mathrm{Agar}$ & 15.0 \\
\hline
\end{tabular}

For isolation of microscopic fungi Sabouraud Dextrose Agar with Chloramphenicol was used (Table 5) [28]. Ten grams ( $10 \pm 0.2 \mathrm{~g}$ ) of soil sample was dispersed in $90 \mathrm{~mL}$ of autoclaved $0.9 \%$ saline and mixed with a magnetic stirrer for $30 \mathrm{~min}$. Serial dilutions to $10^{-4}$ were made for each soil sample, $0.1 \mathrm{ml}$ of each dilution was spread on Sabouraud Dextrose Agar with Chloramphenicol and incubated at $25{ }^{\circ} \mathrm{C}$ for up to five days. The suitable colony counting range was $20-100$ colonies per plate.

Table 5. Composition of Sabouraud Dextrose Agar with Chloramphenicol g/L.

\begin{tabular}{cl}
\hline Glucose & 40.0 \\
\hline Peptone & 10.0 \\
\hline Chloramphenicol & 0.05 \\
\hline Agar & 15.0 \\
\hline
\end{tabular}

\subsection{Microbial Identification}

The culture of the selected microorganisms was purified to single colonies and transferred to petri dishes with Nutrient Broth medium for bacteria and Potato Dextrose agar for fungi. Prepared samples for identification of microorganisms were sent to BaseClear laboratory for the detection of samples. The goal was to identify bacterial and fungal samples using the validated MicroSEQ ${ }^{\circledR}$ system from Applied Biosystems. This automated system is based on PCR amplification and DNA sequencing of bacterial (16S rDNA) or fungal (D2-LSU rRNA) genes. These genes are highly conserved among microbial species and allow for simple and fast identification.

After DNA lysis of the sample, the $16 \mathrm{~S}$ ribosomal DNA (bacterial samples) or the D2LSU gene (fungal samples) was amplified by PCR. PCR is then followed by a sequencing 
step. Samples were detected and analyzed using capillary electrophoresis and results were analyzed against the validated MicroSEQ library. The analysis was carried out according to the manufacturer's specifications. For confirmation of results, public databases were double checked.

\subsection{Statistical Analysis}

The data were analyzed using software STATISTICA Base (version 6). One-way analysis of variance (ANOVA) was applied to evaluate the significance of differences between the means of the experimental data. The data were compared using Fisher's least significant difference (LSD) test at the probability levels $p<0.05$ and $p<0.01$. Principal component analysis was performed.

\section{Conclusions}

Under drought conditions, bio-products with Trichoderma reesei, Acinetobacter calcoaceticus and Bacillus megaterium caused increases in SOC content, aggregate stability, C/N ratio, humic to fulvic acids ratio. All tested bio-products caused an increase in soil respiration. The highest respiration was observed in soil after application of a mixture with three products: Trichoderma reesei + Acinetobacter calcoaceticus + Bacillus megaterium. This was 23.7-26.5\% higher compared to soil respiration in crop growing technologies without bioproducts. The highest AWCD index and R index was found in treatments after application with a mixture of three products: Trichoderma reesei + Acinetobacter calcoaceticus + Bacillus megaterium.

The bio-amendments investigated exhibited potential value as means for soil viability and sustainability under climate change conditions in Cambisols. Future research is needed on different soil types and textures.

Author Contributions: Conceptualization, A.J. and D.F.; methodology, D.F.; validation, A.J. and D.F.; formal analysis, A.J.; investigation, A.J.; data curation, A.J.; writing—original draft preparation, A.J.; writing—review and editing, D.F.; visualization, A.J.; supervision, D.F.; project administration, A.J. and D.F. Both authors have read and agreed to the published version of the manuscript.

Funding: This research received no external funding.

Institutional Review Board Statement: Not applicable.

Informed Consent Statement: Not applicable.

Conflicts of Interest: No conflicts of interest.

\section{References}

1. Chen, R.; Senbayram, M.; Blagodatsky, S.; Myachina, O.; Dittert, K.; Lin, X.; Blagodatskaya, E.; Kuzyakov, Y. Soil C and N Availability Determine the Priming Effect: Microbial N Mining and Stoichiometric Decomposition Theories. Glob. Chang. Biol. 2014, 20, 2356-2367. [CrossRef] [PubMed]

2. Coonan, E.C.; Kirkby, C.A.; Kirkegaard, J.A.; Amidy, M.R.; Strong, C.L.; Richardson, A.E. Microorganisms and Nutrient Stoichiometry as Mediators of Soil Organic Matter Dynamics. Nutr. Cycl. Agroecosyst. 2020, 117, 273-298. [CrossRef]

3. Aziz, I.; Mahmood, T.; Islam, K.R. Effect of Long Term No-till and Conventional Tillage Practices on Soil Quality. Soil Tillage Res. 2013, 131, 28-35. [CrossRef]

4. Mącik, M.; Gryta, A.; Frąc, M. Biofertilizers in agriculture: An overview on concepts, strategies and effects on soil microorganisms. Adv. Agron. 2020, 162, 31-87. [CrossRef]

5. Hammad, H.M.; Khaliq, A.; Abbas, F.; Farhad, W.; Fahad, S.; Aslam, M.; Shah, G.M.; Nasim, W.; Mubeen, M.; Bakhat, H.F. Comparative Effects of Organic and Inorganic Fertilizers on Soil Organic Carbon and Wheat Productivity under Arid Region. Commun. Soil Sci. Plant Anal. 2020, 51, 1406-1422. [CrossRef]

6. Delgado-Baquerizo, M.; García-Palacios, P.; Milla, R.; Gallardo, A.; Maestre, F.T. Soil Characteristics Determine Soil Carbon and Nitrogen Availability during Leaf Litter Decomposition Regardless of Litter Quality. Soil Biol. Biochem. 2015, 81, 134-142. [CrossRef]

7. Jacoby, R.; Peukert, M.; Succurro, A.; Koprivova, A.; Kopriva, S. The Role of Soil Microorganisms in Plant Mineral NutritionCurrent Knowledge and Future Directions. Front. Plant Sci. 2017, 8, 1617. [CrossRef]

8. Sasse, J.; Martinoia, E.; Northen, T. Feed Your Friends: Do Plant Exudates Shape the Root Microbiome? Trends Plant Sci. 2018, 23, 25-41. [CrossRef] 
9. de Graaff, M.A.; Classen, A.T.; Castro, H.F.; Schadt, C.W. Labile Soil Carbon Inputs Mediate the Soil Microbial Community Composition and Plant Residue Decomposition Rates. New Phytol. 2010, 188, 1055-1064. [CrossRef]

10. Venturi, V.; Keel, C. Signaling in the Rhizosphere. Trends Plant Sci. 2016, 21, 187-198. [CrossRef]

11. Pieterse, C.M.J.; Zamioudis, C.; Berendsen, R.L.; Weller, D.M.; van Wees, S.C.M.; Bakker, P.A.H.M. Induced Systemic Resistance by Beneficial Microbes. Annu. Rev. Phytopathol. 2014, 52, 347-375. [CrossRef]

12. Nascimento, F.X.; Hernández, A.G.; Glick, B.R.; Rossi, M.J. Plant Growth-Promoting Activities and Genomic Analysis of the Stress-Resistant Bacillus Megaterium STB1, a Bacterium of Agricultural and Biotechnological Interest. Biotechnol. Rep. 2020, 25. [CrossRef]

13. Shinwari, Z.; Bot, P.J.; Kang, S.-M.; Latif Khan, A.; Hamayun, M.; Shinwari, Z.K.; Kim, Y.-H.; Joo, G.-J.; Lee, I.-J. Acinetobacter Calcoaceticus Ameliorated Plant Growth and Influenced Gibberellins and Functional Biochemicals. Pak. J. Bot. 2012, 44, 365-372.

14. Sachdev, D.; Nema, P.; Dhakephalkar, P.; Zinjarde, S.; Chopade, B. Assessment of 16S RRNA Gene-Based Phylogenetic Diversity and Promising Plant Growth-Promoting Traits of Acinetobacter Community from the Rhizosphere of Wheat. Microbiol. Res. 2010, 165, 627-638. [CrossRef]

15. Peciulyte, A.; Anasontzis, G.E.; Karlström, K.; Larsson, P.T.; Olsson, L. Morphology and Enzyme Production of Trichoderma Reesei Rut C-30 Are Affected by the Physical and Structural Characteristics of Cellulosic Substrates. Fungal Genet. Biol. 2014, 72, 64-72. [CrossRef]

16. Adav, S.S.; Sze, S.K. Trichoderma Secretome: An Overview. In Biotechnology and Biology of Trichoderma; Elsevier: Amsterdam, The Netherlands, 2014; pp. 103-114. ISBN 978-0-444-59576-8.

17. Adav, S.S.; Chao, L.T.; Sze, S.K. Quantitative Secretomic Analysis of Trichoderma Reesei Strains Reveals Enzymatic Composition for Lignocellulosic Biomass Degradation. Mol. Cell. Proteom. 2012, 11, M111.012419-1-M111.012419-15. [CrossRef]

18. Larney, F.J.; Angers, D.A. The Role of Organic Amendments in Soil Reclamation: A Review. Can. J. Soil Sci. 2012, 92, 19-38. [CrossRef]

19. Nuzzo, A.; Satpute, A.; Albrecht, U.; Strauss, S.L. Impact of Soil Microbial Amendments on Tomato Rhizosphere Microbiome and Plant Growth in Field Soil. Microb. Ecol. 2020, 80, 398-409. [CrossRef]

20. Sessitsch, A.; Brader, G.; Pfaffenbichler, N.; Gusenbauer, D.; Mitter, B. The Contribution of Plant Microbiota to Economy Growth. Microb. Biotechnol. 2018, 11, 801-805. [CrossRef]

21. van Veen, J.A.; van Overbeek, L.S.; Dirk, J.; Elsas, V. Fate and Activity of Microorganisms Introduced into Soil. Microbiol. Mol. Biol. Rev. 1997, 61, 121-135. [CrossRef] [PubMed]

22. Trivedi, P.; Singh, K.; Pankaj, U.; Verma, S.K.; Verma, R.K.; Patra, D.D. Effect of Organic Amendments and Microbial Application on Sodic Soil Properties and Growth of an Aromatic Crop. Ecol. Eng. 2017, 102, 127-136. [CrossRef]

23. Pii, Y.; Mimmo, T.; Tomasi, N.; Terzano, R.; Cesco, S.; Crecchio, C. Microbial Interactions in the Rhizosphere: Beneficial Influences of Plant Growth-Promoting Rhizobacteria on Nutrient Acquisition Process. A Review. Biol. Fertil. Soils 2015, 51, 403-415. [CrossRef]

24. Schmidt, M.W.I.; Skjemstad, J.O.; Gehrt, E.; Kögel-Knabner, I. Charred organic carbon in German chernozemic soils. Eur. J. Soil Sci. 1999, 50, 351-365. [CrossRef]

25. Garland, J.L.; Mills, A.L. Classification and Characterization of Heterotrophic Microbial Communities on the Basis of Patterns of Community-Level Sole-Carbon-Source Utilization. Appl. Environ. Microbiol. 1991, 57, 2351-2359. [CrossRef] [PubMed]

26. Wan, W.; Qin, Y.; Wu, H.; Zuo, W.; He, H.; Tan, J.; Wang, Y.; He, D. Isolation and Characterization of Phosphorus Solubilizing Bacteria With Multiple Phosphorus Sources Utilizing Capability and Their Potential for Lead Immobilization in Soil. Front. Microbiol. 2020, 11, 752. [CrossRef] [PubMed]

27. Nautiyal, C.S. An Efficient Microbiological Growth Medium for Screening Phosphate Solubilizing Microorganisms. FEMS Microbiol. Lett. 1999, 170, 265-270. [CrossRef]

28. Vargas Gil, S.; Pastor, S.; March, G.J. Quantitative Isolation of Biocontrol Agents Trichoderma spp., Gliocladium spp. and Actinomycetes from Soil with Culture Media. Microbiol. Res. 2009, 164, 196-205. [CrossRef] 